\title{
救命救急センター・大学病院救急部に打ける 外傷登録の現状
}

市川 政雄 中原 慎二 若井 晋

\begin{abstract}
要旨 全国の救命救急七ンターと大学病院救急部に抢ける外傷登録の現状とそのデータベース化 における問題点を検討するため，アンケート調査を実施した。上記全224施設に調查票を郵送し， 84 施設から回答を得た（回収率 $38 \%$ )。調查票の内容はおもに各施設における診療記録のデー夕 ベース化の現状とその問題点, 日本外傷学会が試案した外傷登録データベース「日本外傷デー夕 バンク $(\mathrm{JTDB}) 」 に$ 対する期待，参加予定についてである。回答施設のうち 47 施設（56\%）が診 療記録をデータベース化しており，そのうち入力スタッフを有していたのは9施設であった。デー タベース化におけるおもな問題点として，入力に伴う負担と入力情報の質の問題が挙げられた。そ の対策として入力スタッフの確保・育成，人件費の予算化，入力作業と入力項目の簡素化などの 必要性が指摘された。JTDBへの参加は 61 施設が予定しており，JTDBに対しては医療の質の向 上，病院間·地域間格差の是正，スタッフの外傷に対する意識の向上，救急隊との情報の共有，事 故防止の観点から期待が寄せられていた。JTDBは医療の質の監査だけでなく，入力負担の軽減や 入力情報の質の向上にも資することから，その普及が望まれる。

(日救急医会誌 $2005 ; 16 ： 149-56$ )

キーワード：外傷登録, データベース, 日本外傷データバンク
\end{abstract}

\section{はじめに}

外傷登録（trauma registry）は他の疾病登録と同様 に，医療の質を系統的に監査（audit）するうえで重 要である1)。わが国では1980年代後半から，医療の 質を第三者が評価することへの気運が高まり，1995 年には病院の第三者評価事業が開始された ${ }^{2)}$ 。外傷 登録は今日，外傷診療に関わる医療の質を保証する うえで不可欠なものとなった。

外傷登録は事故サーベイランス (injury surveillance) の情報源にもなる ${ }^{1,3)}$ 。わが国では2003年に，外傷を 含む疾病登録のデータベース化が全国の救命救急七

Trauma registries in Japan

東京大学大学院医学系研究科国際地域保健学教室

著者連絡先：干113-0033 文京区本郷 7-3-1

原稿受理日：2004年 10 月 22 日（04-064）
ンターを中心に開始されだ)。疾病登録のデータベー ス化は，それに際して施設間の臨床評価指標 (clinical indicator) が標準化されるため, 救命救急センターを 定点とした事故サーベイランスに発展することが期 待される。

欧米では効果的な外傷予防と事故対策を実現する ため，全国規模で事故サーベイランスが実施されて いるが5-7)，わが国では限られた地域での試みにとど まっている。事故サーベイランスの目的は，事故の 発生状況 - 要因, 事故対策の効果などを集団 (population) レベルで検討することにある ${ }^{8,9)}$ 。救命 救急センターを中心とした外傷登録の全国規模での データベース化は，わが国における事故サーベイラ ンスの試金石となる。

外傷登録をデータベース化するためには，各施設 の外傷登録の内容や方法を統一する必要がある。そ 
市川 政雄, 他

のため，新たに定められた登録内容が既存項目より 多い施設や登録方法の変更に対応できない施設に とって，外傷登録のデータベース化への参加は大き な負担になることが予想される。外傷登録のデー夕 ベース化を拡充していくためには，各施設における 今までの外傷登録の実績やスタッフの体制を把握し ておく必要がある。

本研究では全国の救命救急センターと大学病院救 急部を対象に，各施設における外傷登録の現状を調 査するとともに，データベース化における問題点を 検討した。

\section{方法}

全国の救命救急センターならびに大学病院救急部 を対象にアンケート調查を実施した。平成 15 年 1 月 1 日現在，救命救急センターは165施設に設置され10), すべての施設を対象にした。大学病院は防衛医科大 学校病院を含め 146 施設あり ${ }^{11)}$, そのうち 40 施設に 救命救急センターが設置されていた。残りの106施設 のうち59施設に救急部が設置され，それらの施設を 対象にした。調査票は上記 224 施設に対して平成 15 年 8 月に郵送し，同年12月末までに有効な調査票を 救命救急センター57施設 (回収率 $35 \%$ ), 大学病院救 急部 27 施設（回収率46\%），計 84 施設（回収率 $38 \%$ ) より回収した。

調査票では，まず各施設における診療記録のデー タベース化（コンピュータ入力）について，その開 始時期, データベースのソフト名, データ入力のた めに優先して使えるコンピュータの有無, データ入 力担当者に関して質問した。データ入力の負担度合 は 1 点（負担小）から 10 点（負担大）の尺度で, 調 査票の回答者が評価した。データベース化における 問題点やその対策については自由回答を求めた。

次に, 日本外傷学会が試案した外傷登録のデー夕 ベース「日本外傷データバンク (JTDB)」の入力項 目（患者初期情報 7 項目, 病院前情報 14 項目, 転送 情報 7 項目, 来院時病態13項目, 初療時の検査と処 置15項目, 診断名と損傷重症度 9 項目, 入院退院情
報11項目）計 76項目が現在，各施設の診療記録（コ ンピュータ入力している場合はその項目）に含まれ ているか，含まれていない場合は追加可能かどうか を質問した4)。また，外傷診断名として使用している コードについても質問した。

JTDBに対する期待については自由回答を求め，そ の度合は医療の質の評価と研究における有用性の 2 つの側面について，1点（期待小）から 10 点（期待 大)の尺度で，調査票の回答者が評価した。JTDBへ の参加予定についても質問し，不参加の場合，その 理由を尋ねた。

施設の基本情報として, 救命救急センター・大学 病院救急部のスタッフ数 (医師，研修医，看護師，そ の他）と外傷患者数を質問した。外傷患者数は救命 救急センター・大学病院救急部の病床に入院した外 傷患者の数と定義した。本研究ではおもに上記デー 夕の記述統計量を算出した。

\section{結果}

\section{（1）回答施設の特徵}

84 施設のうち，29施設（35\%）が医師 10 人以上, 35 施設 $(48 \%)$ が看護師 40 人以上のスタッフを有し ており，日中週 3 日以上勤務する医師が 10 人以上の 施設は 28 施設 $(33.3 \%)$ あった。 31 施設 $(48.4 \%)$ が 過去 1 年間に 200 人以上の入院患者を受け入れてい た。なお，救命救急センター・大学病院救急部スタッ フが施設によっては他科と兼務していること，また 救急専門の病床を設けていない施設があることから， スタッフ数や入院患者数は施設の規模を示す指標で はない。

\section{（2）診療記録のデータベース化の現状（Table 1）}

84 施設のうち，47 施設（56\%）が診療記録をデー 夕ベース化しており，その運用年数は平均 5 年であっ た。データベースに用いられているおもなソフトは ファイルメーカー $(76 \%)$ ，それ以外にはエクセルや アクセス，オラクルなどが用いられていた。診療記録 をデータベース化している施設のうち，データ入力 
Table 1. Current status of the trauma registry.

\begin{tabular}{|c|c|c|c|}
\hline & No. of response & $\mathrm{n}$ & $\%$ \\
\hline Using computerized registry & 84 & 47 & 56 \\
\hline Duration of the use of the trauma registry (years, mean [SD]) & 45 & \multicolumn{2}{|c|}{$5.0(4.1)$} \\
\hline Software for the computerized registry & 46 & & \\
\hline File Maker & & 33 & 72 \\
\hline Excel & & 4 & 9 \\
\hline Access & & 3 & 7 \\
\hline File Maker / Excel & & 2 & 4 \\
\hline Oracle & & 1 & 2 \\
\hline Others & & 3 & 7 \\
\hline Computer available exclusively for data entry & 47 & 39 & 83 \\
\hline Main staff for data entry & 47 & & \\
\hline Medical doctor (MD) & & 35 & 75 \\
\hline Non-medical staff & & 6 & 13 \\
\hline MD and resident & & 2 & 4 \\
\hline MD and nurses & & 2 & 4 \\
\hline Resident & & 1 & 2 \\
\hline MD and non-medical staff & & 1 & 2 \\
\hline Availability of the staff for data entry & 47 & & \\
\hline Available & & 9 & 19 \\
\hline Not available but will be employed & & 2 & 4 \\
\hline Not available and will not be employed & & 36 & 77 \\
\hline No. of the staff for data entry & 8 & & \\
\hline One person & & 6 & 75 \\
\hline Two persons & & 1 & 13 \\
\hline Three persons & & 1 & 13 \\
\hline Reasons for not employing the staff for data entry $*$ & 34 & & \\
\hline No budget & & 31 & 91 \\
\hline Fixed employment capacity & & 4 & 12 \\
\hline Perceived burden of the data entry, (mean [SD]) & 47 & & \\
\hline
\end{tabular}

* Multiple answers included.

用のコンピュータがある施設は 41 施設 $(77 \%)$, 入力 スタッフを有する施設は 9 施設 $(17 \%)$, 入力スタッ フの雇用を予定している施設は 2 施設 $(4 \%)$ あっ た。現在のおもなデータ入力者は多くの場合, 医療従 事者(医師，研修医，看護師)であるが，6施設 (12\%) においては医療従事者以外のスタッフがデータ入力 に当たっていた。入力スタッフを雇用する予定がな い施設の 9 割は, 雇用できないおもな理由として予 算不足を挙げた。データ入力の負担度合は平均 6.9 点 たった。

\section{（3）データベース化の問題点とその対策}

データベース化におけるおもな問題点は, 入力に 伴う負担と入力情報の質に関することであった。入 力の負担はとくに人手不足に起因すると指摘された。 また，入力や入力情報の収集それ自体に時間がかか ること, 専門知識をもつ医師がデータ入力せざるを 得ないため, 診療外業務が増加すること, コーディ ング・ルールを熟知したスタッフがいないこと，コ ンピュータ操作そのものに時間がかかることなども 指摘された。 
一方，入力情報の質については医師によって記録 がまちまちであったり, 患者の転科後の追跡調査が 不十分で入力漏れがあったり, 多発外傷の場合, 傷 病名の統一が困難という意見が挙げられた。また， 診療記録からデータベースに情報を転記している施 設では入力ミスやリアルタイムで集計できないこと が問題として挙げられた。その他, プライバシー保 護の問題やデータベース化の目的が不明瞭であるこ とが指摘された。

これらの問題の対策として, 入力スタッフの確保 とその人件費の予算化の必要性が指摘された。入力 には専門知識を要することもあるので, 米国の外傷 センターのように専門知識をもった入力スタッフを 育成することが提案された。また，第三者機関で入 力するという意見もあった。

スタッフの拡充・育成以外には, 入力と入力項目 の簡素化, 入力マニュアルの作成, 入力のためのサ ポートセンターの設立, 電子カルテとデータベース のデー夕連結，そのためのソフトウェアの開発が, 入力の負担を軽減する方策として指摘された。診療 記録の音声入力を予定している施設もあった。問題 の解決には，データベース化の重要性について医師 の意識を向上させる必要があるという意見もあった。

\section{（4）外傷診断名の使用コード（Table 2)}

外傷診断コードのうちもっとも使用されている コードはICD10 (45\%), 続いて AIS90（23\%), ICD とAISを併用している施設もあった $(17 \%)$ 。25施設 (30\%) はいずれのコードも使用していなかった。

\section{（5）各施設における JTDB の入力項目の有無（Table 3）}

$\mathrm{JTDB}$ の入力項目に該当する項目が, 半数以上の施 設の既存データベースに含まれていない項目は，患 者初期情報 7 項目中 1 項目, 病院前情報14項目中 10 項目, 転送情報 7 項目すべて, 来院時病態13項目中 3 項目, 初療時の検査と処置15項目中 10 項目, 診断 名と損傷重症度 9 項目すべて, 入院退院情報 11 項目 中 2 項目であった。
Table 2. Current use of the injury codes $(n=83) *$.

\begin{tabular}{lrr}
\hline & $\mathrm{n}$ & $\%$ \\
\hline ICD9 & 2 & 2 \\
ICD10 & 37 & 45 \\
ICD-DM & 1 & 1 \\
AIS85 & 14 & 17 \\
AIS90 & 19 & 23 \\
None in use & 25 & 30 \\
\hline
\end{tabular}

* Multiple answers included.

一方， 2 割以上の施設が追加不可能と答えた項目 は, 病院前情報14項目中 7 項目, 転送情報 7 項目中 5 項目, 来院時病態 13 項目中 2 項目, 初療時の検査 と処置15項目中 2 項目, 診断名と損傷重症度 9 項目 中 3 項目, 入院退院情報 11 項目中 1 項目であった。 患者初期情報はすべて追加可能であった。

\section{（6）JTDB への参加予定と期待度合}

JTDBへの参加の有無を回答した 80 施設のうち 61 施設 $(76.3 \%)$ が参加を予定していると答えた。参加 しない施設はその理由として，データベース化にお ける問題点でも指摘された入力の負担と人手不足が 挙げられた。入力に伴う負担に見合うだけの成果が 期待できるのかどうか, また個人情報の保護が万全 なのかどうか危惧する意見もあった。

JTDBに対する期待度合は, 医療の質の評価につい ては平均7.4点 (標準偏差1.9点), 研究における有用 性については平均 7.5 点（標準偏差 1.8）だった。具 体的には，医療の質の向上や病院間 ·地域間格差の 是正, スタッフの外傷に対する意識の向上, 救急隊 との情報の共有, 事故防止にJTDB が役立つと期待 する声が寄せられた。

一方, JTDBに対する要望や限界も指摘された。た とえば，JTDBはプロセス指標が中心なのでアウトカ 厶指標も充実させること, 入力されたデー夕の正確 さを定期的に確認する作業の必要性が指摘された。 また，JTDBはおもに三次医療を対象にしており，ま た大都市から地方都市まで広範囲の医療施設を対象 にしているため，それに起因するバイアスを医療の 
Table 3-1. Availability in the current registry of the data required for the Japan Trauma Data Bank.

\begin{tabular}{|c|c|c|c|c|c|c|c|}
\hline \multirow[t]{2}{*}{ Data content } & \multirow[t]{2}{*}{$\begin{array}{l}\text { No. of } \\
\text { response }\end{array}$} & \multicolumn{2}{|c|}{ Available } & \multicolumn{2}{|c|}{$\begin{array}{c}\text { Possible } \\
\text { to add }\end{array}$} & \multicolumn{2}{|c|}{$\begin{array}{c}\text { Impossible } \\
\text { to add }\end{array}$} \\
\hline & & $\mathrm{n}$ & $\%$ & $\mathrm{n}$ & $\%$ & $\mathrm{n}$ & $\%$ \\
\hline \multicolumn{8}{|l|}{ Demographic data/Incident description } \\
\hline 1. Age & 80 & 78 & 98 & 2 & 3 & 0 & 0 \\
\hline 2. Sex & 80 & 78 & 98 & 2 & 3 & 0 & 0 \\
\hline 3. Date of injury occurrence & 80 & 75 & 94 & 4 & 5 & 1 & 1 \\
\hline 4. Time of injury occurrence & 77 & 37 & 48 & 30 & 39 & 10 & 13 \\
\hline 5. Cause of injury & 78 & 55 & 71 & 15 & 19 & 8 & 10 \\
\hline 6. Type of injury & 79 & 42 & 53 & 29 & 37 & 8 & 10 \\
\hline 7. Mechanism of injury & 77 & 41 & 53 & 26 & 34 & 10 & 13 \\
\hline \multicolumn{8}{|l|}{ Prehospital information } \\
\hline 1. Route of transportation to hospital & 79 & 67 & 85 & 10 & 13 & 2 & 3 \\
\hline 2. Mode of transportation to hospital & 79 & 60 & 76 & 15 & 19 & 4 & 5 \\
\hline 3. Name of the fire department dispatching ambulance team & 78 & 50 & 64 & 18 & 23 & 10 & 13 \\
\hline 4. Date and time of dispatching ambulance team & 78 & 36 & 46 & 32 & 41 & 10 & 13 \\
\hline 5. Date and time of arrival of ambulance team at scene & 78 & 34 & 44 & 34 & 44 & 10 & 13 \\
\hline 6. Date and time of contact with patient at scene & 77 & 19 & 25 & 40 & 52 & 18 & 23 \\
\hline 7. Date and time of departure at scene to hospital & 78 & 28 & 36 & 38 & 49 & 12 & 15 \\
\hline 8. Date and time of arrival at hospital & 79 & 50 & 63 & 22 & 28 & 7 & 9 \\
\hline 9. Availability of emergency life-saving technician in ambulance team & 77 & 19 & 25 & 42 & 55 & 16 & 21 \\
\hline 10. Prehospital care & 78 & 22 & 28 & 37 & 47 & 19 & 24 \\
\hline 11. Blood pressure at scene & 78 & 24 & 31 & 37 & 47 & 17 & 22 \\
\hline 12. Pulse rate at scene & 78 & 24 & 31 & 38 & 49 & 16 & 21 \\
\hline 13. Respiratory rate at scene & 78 & 23 & 29 & 39 & 50 & 16 & 21 \\
\hline 14. JCS at scene & 78 & 24 & 31 & 38 & 49 & 16 & 21 \\
\hline \multicolumn{8}{|l|}{ Transfer information } \\
\hline 1. Name of the fire department initially contacted & 77 & 33 & 43 & 31 & 40 & 13 & 17 \\
\hline 2. Type of transferring hospital & 77 & 37 & 48 & 27 & 35 & 13 & 17 \\
\hline 3. Reasons for transfer & 78 & 20 & 26 & 38 & 49 & 20 & 26 \\
\hline 4. Date of admission to transferring hospital & 77 & 24 & 31 & 36 & 47 & 17 & 22 \\
\hline 5. Time of admission to transferring hospital & 76 & 12 & 16 & 34 & 45 & 30 & 39 \\
\hline 6. Date and time of departure at transferring hospital & 75 & 23 & 31 & 35 & 47 & 17 & 23 \\
\hline 7. Number of hospitals transferred & 76 & 15 & 20 & 38 & 50 & 23 & 30 \\
\hline \multicolumn{8}{|l|}{ Patient condition at admission } \\
\hline 1. Systolic blood pressure & 78 & 54 & 69 & 20 & 26 & 4 & 5 \\
\hline 2. Diastolic blood pressure & 78 & 49 & 63 & 25 & 32 & 4 & 5 \\
\hline 3. Respiratory rate & 78 & 51 & 65 & 23 & 29 & 4 & 5 \\
\hline 4. Pulse rate & 78 & 53 & 68 & 21 & 27 & 4 & 5 \\
\hline 5. Temperature $\left({ }^{\circ} \mathrm{C}\right)$ & 78 & 47 & 60 & 27 & 35 & 4 & 5 \\
\hline 6. Region of temperature measurement & 76 & 30 & 39 & 32 & 42 & 14 & 18 \\
\hline 7. GCS-Eye response & 77 & 41 & 53 & 25 & 32 & 11 & 14 \\
\hline 8. GCS-Verbal response & 77 & 41 & 53 & 25 & 32 & 11 & 14 \\
\hline 9. GCS-Motor response & 76 & 41 & 54 & 24 & 32 & 11 & 14 \\
\hline 10. JCS & 76 & 47 & 62 & 22 & 29 & 7 & 9 \\
\hline 11. Alcohol drinking before injury occurrence & 78 & 19 & 24 & 42 & 54 & 17 & 22 \\
\hline 12. Blood alcohol concentration & 76 & 8 & 11 & 23 & 30 & 45 & 59 \\
\hline 13. Medical history & 78 & 40 & 51 & 31 & 40 & 7 & 9 \\
\hline
\end{tabular}


Table 3-2. Availability in the current registry of the data required for the Japan Trauma Data Bank.

\begin{tabular}{|c|c|c|c|c|c|c|c|}
\hline \multirow[t]{2}{*}{ Data content } & \multirow[t]{2}{*}{$\begin{array}{l}\text { No. of } \\
\text { response }\end{array}$} & \multicolumn{2}{|c|}{ Available } & \multicolumn{2}{|c|}{$\begin{array}{c}\text { Possible } \\
\text { to add }\end{array}$} & \multicolumn{2}{|c|}{$\begin{array}{l}\text { Impossible } \\
\text { to add }\end{array}$} \\
\hline & & $\mathrm{n}$ & $\%$ & $\mathrm{n}$ & $\%$ & $\mathrm{n}$ & $\%$ \\
\hline \multicolumn{8}{|l|}{ Initial assessment and care } \\
\hline 1. Time of assessment and care by doctors & 78 & 38 & 49 & 30 & 38 & 10 & 13 \\
\hline 2. Focused Assessment with Sonography for Trauma & 78 & 31 & 40 & 36 & 46 & 11 & 14 \\
\hline 3. CT scan & 78 & 39 & 50 & 32 & 41 & 7 & 9 \\
\hline 4. Time of starting CT scanning & 76 & 21 & 28 & 39 & 51 & 16 & 21 \\
\hline 5. Angiography & 78 & 37 & 47 & 32 & 41 & 9 & 12 \\
\hline 6. Time of starting angiography & 77 & 19 & 25 & 41 & 53 & 17 & 22 \\
\hline 7. Cardiopulmonary resuscitation & 77 & 45 & 58 & 26 & 34 & 6 & 8 \\
\hline 8. Time of starting blood transfusion & 77 & 23 & 30 & 41 & 53 & 13 & 17 \\
\hline 9. Volume of blood transfusion for the first 24 hours & 77 & 27 & 35 & 39 & 51 & 11 & 14 \\
\hline 10. Type of first operation & 78 & 46 & 59 & 27 & 35 & 5 & 6 \\
\hline 11. Date of first operation & 78 & 54 & 69 & 18 & 23 & 6 & 8 \\
\hline 12. Time of first operation & 77 & 30 & 39 & 35 & 45 & 12 & 16 \\
\hline 13. Purposes of surgical care, by body region & 78 & 29 & 37 & 36 & 46 & 13 & 17 \\
\hline 14. Type of surgical care, by body region & 78 & 50 & 64 & 22 & 28 & 6 & 8 \\
\hline 15. Re-operation within 48 hours after first operation & 77 & 29 & 38 & 40 & 52 & 8 & 10 \\
\hline \multicolumn{8}{|l|}{ Diagnosis/Injury severity } \\
\hline 1. Head AIS & 79 & 33 & 42 & 32 & 41 & 14 & 18 \\
\hline 2. Face AIS & 79 & 33 & 42 & 32 & 41 & 14 & 18 \\
\hline 3. Chest AIS & 79 & 34 & 43 & 31 & 39 & 14 & 18 \\
\hline 4. Abdomen AIS & 79 & 34 & 43 & 31 & 39 & 14 & 18 \\
\hline 5. Extremities AIS & 79 & 34 & 43 & 31 & 39 & 14 & 18 \\
\hline 6. External AIS & 79 & 33 & 42 & 32 & 41 & 14 & 18 \\
\hline 7. JAST classification of injury & 78 & 15 & 19 & 44 & 56 & 19 & 24 \\
\hline 8. TCDB classification of head injury & 78 & 8 & 10 & 50 & 64 & 20 & 26 \\
\hline 9. Complications & 78 & 22 & 28 & 40 & 51 & 16 & 21 \\
\hline \multicolumn{8}{|l|}{ Admission and discharge information } \\
\hline 1. Date and time of admission & 78 & 72 & 92 & 6 & 8 & 0 & 0 \\
\hline 2. Admission to ICU & 78 & 59 & 76 & 13 & 17 & 6 & 8 \\
\hline 3. Department in charge after admission & 79 & 66 & 84 & 11 & 14 & 2 & 3 \\
\hline 4. Number of days using artificial respiration & 76 & 27 & 36 & 37 & 49 & 12 & 16 \\
\hline 5. Number of days in ICU & 79 & 40 & 51 & 31 & 39 & 8 & 10 \\
\hline 6. Date and time of transfer from emergency department & 79 & 51 & 65 & 23 & 29 & 5 & 6 \\
\hline 7. Date and time of discharge from hospital & 78 & 53 & 68 & 18 & 23 & 7 & 9 \\
\hline 8. Receiving facility after discharge & 78 & 43 & 55 & 27 & 35 & 8 & 10 \\
\hline 9. Functional independence at discharge & 76 & 13 & 17 & 42 & 55 & 21 & 28 \\
\hline 10. Time of death & 78 & 51 & 65 & 22 & 28 & 5 & 6 \\
\hline 11. Autopsy & 78 & 44 & 56 & 24 & 31 & 10 & 13 \\
\hline
\end{tabular}

Abbreviations: AIS, Abbreviated Injury Score; ICU, intensive care unit; GCS, Glasgow Coma Scale; JCS, Japan Coma Scale; JAST, Japanese Association for the Surgery of Trauma; TCDB, Traumatic Coma Data Bank.

質を評価する際に考慮する必要があるという意見も

あった。 
は，その新たなシステムが各施設において受け入れ られるものでなければならない。本研究で示された 外傷登録の現状については低い回答率のため,その 一般化には注意を要するものの，JTDBの推進にあた り考慮すべきいくつかの課題が明らかとなった。

まず，診療記録をコンピュータ入力していない施 設が半数近くあった。それらの施設はコンピュータ 入力に対応するため, データベースを構築する必要 がある。JTDBに参加すれば，新たにデータベースを 構築する手間は省けるが，新たに始めるにはそれだ けの人手や時間を割かなければならない。

一方, コンピュータ入力している施設ではすでに さまざまなデータベースソフトが利用されているた め，新たな入力方式と競合することになる。現在の システムでは各施設のデータベースとJTDB に同じ データを二度入力する必要があるため, その負担は 大きい。そのことがJTDBへの参加を阻む原因にな りかねない。しかし，JTDBに入力したデータは施設 ごとにデータを引き出すことが可能である。各施設 で独自のデータベースを残す必要があれば，JTDBか ら引き出したデー夕を各施設のデータベースに書き 込めばよい。それが可能であれば二度目のデー夕入 力が不要となるため, 入力ミスはなくなり, 手間を 減らすこともできる。

問題は入力システムの変更だけではない。施設に よっては入力項目を相当数増やさなければならない。 追加できない入力項目も決して少なくなく，それを 理由にJTDBに参加しない施設があるかもしれない。 入力項目を追加できない理由は今後の検討課題であ る。一方, 新たな入力項目を追加せずにそれらの施 設がJTDBに参加した場合，欠損の多いデータベー スになる恐れがある。データの欠損は結果にバイア スを生じさせるため, その解釈には十分な配慮を要 する。

データ入力は手間のかかる作業である。入力ス タッフのいない 8 割以上の施設では臨床のかたわら 医療従事者がデータ入力を行っている。前述した $\mathrm{JTDB}$ のシステム上の対応と入力項目の増加の問題
は，入力スタッフの起用である程度は軽減できると 考えられる。しかし，新たに入力スタッフを雇用す る予定の施設はわずか 2 施設（4\%）しかない。入 力スタッフを増員できない以上, データ入力の効率 化を図るしかほかない。

JTDB はその点, システムそのものの利便性は高 い。データ入力はインターネットのウェブ上で対話 形式により行うよう構築されているため，わかりや すい。また，入力にはプルダウンやチェックボタン 方式が多用されているため，入力の手間を省くこと ができる。入力内容はあらかじめ定められているた め，記録者間のデー夕の整合性が問題になることは ない。さらにはISS や TRISS Ps 值などの自動計算機 能が備わっており，手間を省くだけでなく，デー夕 の質を保証するものである。これらの工夫はデー夕 入力の負担を大きく軽減し, データの質を向上させ るものである。こうしたJTDBの長所を理解しても らうことが，対象施設の参加率の向上につながると 考えられる。

各施設においてデータ入力は相当の負担となって いる一方，JTDBへの参加予定施設は回答施設の7割 を超え，JTDB に寄せる期待も高い。本研究のアン ケートに回答しなかった施設がJTDB に対しそれほ ど大きな期待を寄せておらず，参加も予定していな いとすれば，それらの結果は過大評価と言わざるを 得ないが，JTDBが医療の質の監査と事故サーベイラ ンスの情報源として果たす役割は大きいはずである。

謝辞＼cjkstart調査にご協力くださいました全国の救命救急セ ンター, 大学病院救急部ならびに有限責任中間法人日本 救急医学会診療の質評価指標に関する委員会 (坂本哲也 委員長), 日本外傷学会Trauma registry委員会 (小関一英 委員長)に深謝いたします。本研究は文部科学省の科研 費（15790296）の助成を得ました。

\section{文献}

1) Pollock DA, McClain PW: Trauma registries: current status and future prospects. JAMA 1989;262: 2280-3.

2）平成 12 年度厚生科学研究費補助金（特別研究事業）報 
告書「心筋梗塞, 脳卒中などにおける効果的な診療評価 指標と登録手法の開発に関する研究」（主任研究者：有 賀徹)。

3) Layde PM, Stueland DT, Nordstrom DL: Representativeness of trauma center registries for farm injury surveillance. Accid Anal Prev 1996; 28: 581-6.

4) 平成 13 年度厚生科学研究費補助金 (21 世紀型医療開拓 推進研究事業) 総括研究報告書「院内の疾病登録を利用 した心筋梗塞及び脳卒中の治療方針等の向上に関する研 究」(主任研究者: 有賀徹).

5) Stone DH, Morrison A, Ohn TT: Developing injury surveillance in accident and emergency departments. Arch Dis Child 1998; 78: 108-10.

6) Mackenzie SG, Pless IB: CHIRPP: Canada's principal injury surveillance program. Inj Prev 1999; 5: 208-13.

7) Lyons RA, Jones S, Kemp A, et al: Development and use of a population based injury surveillance system: the All Wales Injury Surveillance System (AWISS). Inj Prev 2002; 8: 836.

8) Klauke DN, Buehler JW, Thacker SB: Guidelines for evaluating surveillance systems. Morb Mortal Wkly Rep 1988; 37: 51-5.

9) Holder Y, Peden M, Krug E, et al (Eds): Injury surveillance guidelines. Geneva: World Health Organization, 2001.

10）日本救急医学会：全国救命救急センター一覧. http:// plaza.umin.ac.jp/ jaam/03/list/qqcenter.htm Accessed : 2003 年 5 月 7 日.

11）大学病院医療情報ネットワーク研究 (UMIN) センター： 医学部附属病院·研究所附属病院. http://endai.umin.ac.jp/ cgi-open-bin/hanyou/table/listout.cgi?parm=UHOSP Accessed：2003 年 8 月 12 日.

\section{ABSTRACT \\ Trauma Registries in Japan}

Masao Ichikawa, Shinji Nakahara, and Susumu Wakai

Department of International Community Health, Graduate School of Medicine, University of Tokyo

We conducted a questionnaire survey to investigate problems in the usage of trauma registries at Trauma/Critical Care Centers and Emergency Departments within university hospitals in Japan. Of the 244 facilities, 84 replied via self-administered questionnaire (a response rate of $38 \%$ ). We collected data regarding the management of existing trauma registries and assessed attitudes towards, expectations of and willingness to participate in the newly established Japan Trauma Data Bank (JTDB). The JTDB is a national trauma registry developed by the Japanese Associations of Acute Medicine and the Surgery of Trauma. Of the 84 responding facilities, 47 had computerized trauma registries but only 9 of the 47 facilities employed personnel for data entry. The work-burden involved in physical data entry and the actual quality of the data stored on registries were reported as major problems. To resolve these issues, it was suggested that centers allocate more personnel, make available more funds, reduce the amount of information requiring data entry, and simplify the data being entered. Sixty-one facilities stated their intention to participate in the JTDB. It was felt that the JTDB would lead to improvement in the quality of trauma care; be helpful in bridging the gap in the quality of trauma care between facilities and regions; enhance the awareness of the role of departmental staff; facilitate the sharing of information with emergency service personnel; be helpful for injury control. In sum, the JTDB would not only be useful for the purposes of medical audit but also would be helpful in alleviating the work-burden of data entry and should lead to an improvement in the quality of data collected. Therefore, it would appear reasonable to recommend that all efforts be made to expand the registry's coverage.

(JJAAM $2005 ; 16: 149-56)$

Keywords: trauma registry, database, Japan Trauma Data Bank

Accepted for publication on October 22, $2004 \quad(04-064)$ 